\title{
Milk volatile organic compounds and fatty acid profile in cows fed timothy as hay, pasture, or silage
}

\author{
M.-P. Villeneuve, ${ }^{*}$ Y. Lebeuf, ${ }^{*}$ R. Gervais, ${ }^{*}$ G. F. Tremblay,† J. C. Vuillemard,ł J. Fortin,§ and P. Y. Chouinard ${ }^{* 1}$ \\ *Département des Ssciences Animales, Université Laval, Québec, Québec, Canada G1V 0A6 \\ †Soils and Crops Research and Development Centre, Agriculture and Agri-Food Canada, Québec, Québec, Canada G1V 2J3 \\ łDépartement des Sciences des Aliments et de Nutrition, Université Laval, Québec, Québec, Canada G1V 0A6 \\ §Food Research and Development Centre, Agriculture and Agri-Food Canada, Saint-Hyacinthe, Québec, Canada J2S 8E3
}

\section{ABSTRACT}

Nutrient composition and organoleptic properties of milk can be influenced by cow diets. The objective of this study was to evaluate the forage type effects on volatile organic compounds, fatty acid (FA) profile, and organoleptic properties of milk. Timothy grass was fed as hay, pasture, or silage during a period of $27 \mathrm{~d}$ to a group of 21 cows in a complete block design based on days in milk. Each cow also received $7.2 \mathrm{~kg} / \mathrm{d}$ of a concentrate mix to meet their nutrient requirements. Forage dry matter intake averaged $13.9 \mathrm{~kg} / \mathrm{d}$ and was not different among treatments. Milk yield was higher for cows fed pasture, intermediate for cows fed silage, and lowest for cows fed hay. However, milk fat content was higher for cows fed hay and silage, compared with cows fed pasture. As a result, fat-corrected milk and fat yield were not different among treatments. Increasing the supply of dietary cis-9, cis-12 18:2 (linoleic acid) and cis-9,cis-12,cis-15 18:3 ( $\alpha$-linolenic acid) when feeding pasture enhanced the concentration of these 2 essential FA in milk fat compared with feeding hay or silage. Moreover, the ratio of 16:0 (palmitic acid) to cis-9 18:1 (oleic acid), which is closely related to the melting properties of milk fat, was lower in milk from cows on pasture than in milk from cows fed hay or silage. Cows fed hay produced milk with higher levels of several free FA and $\gamma$-lactones, but less pentanal and 1-pentanol. More dimethyl sulfone and toluene were found in milk of cows on pasture. Cows fed silage produced milk with higher levels of acetone, 2-butanone, and $\alpha$-pinene. Results from a sensory evaluation showed that panelists could not detect a difference in flavor between milk from cows fed hay compared with silage. However, a significant number of assessors perceived a difference between milk from cows fed hay compared with milk from cows fed pasture. In a sensory ranking test, the

Received May 10, 2013.

Accepted July 25, 2013.

${ }^{1}$ Corresponding author: yvan.chouinard@fsaa.ulaval.ca percentage of assessors ranking for the intensity of total (raw milk, fresh milk, and farm milk), sweet (empyreumatic, vanilla, caramel, and sugar), and grassy (grass, leafy vegetable, and plant) flavors was higher for milk from cows fed pasture compared with hay and silage. Using timothy hay, pasture, or silage harvested at a similar stage of development, the current study shows that the taste of milk is affected by the forage type fed to cows. More research is, however, needed to establish a link between the sensory attributes of milk and the observed changes in volatile organic compounds and FA profile.

Key words: milk volatile organic compound, milk fatty acid, solid-phase microextraction, sensory evaluation

\section{INTRODUCTION}

Sensory properties of fluid milk are affected by the concentrations of individual volatile organic compounds. Moreover, the FA profile of milk fat is reported to affect the sensory evaluation of butter. The effects of diets on concentrations of milk volatile compounds have been studied using various laboratory techniques (Bendall, 2001; Toso et al., 2002; Croissant et al., 2007; Coppa et al., 2011). Among comparisons reported on bulk milk samples, Bendall (2001) studied milk from cows fed pasture and TMR in New Zealand. A total of 66 different molecules were evaluated using the nasal impact factor procedure and among the reported profiles, 7 compounds, including 3 lactones, were found to be significantly different between milk from cows fed the 2 diets. In particular, the frequency of detection was lower for cis-3-methyl- $\gamma$-nonalactone and $\gamma$-dodecadienolactone, and higher for $\gamma$-hexadecalactone in milk of cows fed pasture compared with TMR. During a study conducted in Italy, Toso et al. (2002) identified 42 milk compounds using a headspace sampling technique, and a discriminant analysis indicated that aldehydes provided one of the best criteria to be used for grouping milks according to the type of forage in dairy rations (hay, corn silage, or grass silage). 
Much less data are available on organic volatile compounds when comparing the effects of different diets on an individual cow basis. In a feeding trial conducted in France, Coppa et al. (2011) evaluated the effects of feeding a hay- and concentrate-based diet with either a low- or a high-biodiversity pasture in Montbéliarde cows. A total of 74 compounds were identified and quantified in milk using the solid-phase microextraction (SPME) technique. Feeding the high-biodiversity pasture increased the concentrations of several monoterpenes and sesquiterpenes in milk, and this effect was explained by the presence of numerous dicotyledon species in the grazing area.

The FA profile of milk fat can also be affected by feeding in dairy cows (Palmquist et al., 1993; Dewhurst et al., 2006). In relation to organoleptic properties, unsaturated FA could be used as precursors of lactones found in milk (Urbach, 1990). Increasing PUFA concentration in milk fat could also increase the concentration of their oxidation and degradation products. In this regard, $\beta$-oxidation at the double bounds can lead to straight-chain aldehydes and ketones, which may be converted to the corresponding alcohols under reducing conditions (Nursten, 1997). Moreover, major FA concentrations can influence the physical properties of milk fat (perceived firmness and melting in mouth of butter) in relation to the individual melting point of these FA (Couvreur et al., 2006; Hurtaud et al., 2007). Based on these results, it was hypothesized that feeding cows with timothy grass harvested as hay, pasture, or silage at a similar stage of development would affect the formation of volatile organic compounds and FA profile of milk, and therefore influence its sensory properties.

\section{MATERIALS AND METHODS}

\section{Forages, Cows, and Experimental Design}

A 5.3-ha field plot of timothy (Phleum pratense L. cultivar AC Alliance) was used for forage production at the Centre de recherche en sciences animales de Deschambault (Deschambault, QC, Canada). In June 2009 , the timothy grass was cut with a mower conditioner at the late heading stage of development. After $24 \mathrm{~h}$ of wilting, alternate windrows were harvested using a forage chopper, and stored as silage in a plastic bag silo. The remaining windrows were tedded, left to dry, raked, and harvested $2 \mathrm{~d}$ later as rectangular bales of hay. In 2010, the same plot was used as pasture during the feeding trial described below. To attenuate possible bias associated with the stage of development of timothy at harvest, pasture was planned to ensure that timothy had reached the late heading stage during the final collection period.
All procedures performed in this feeding trial were approved by the institutional animal care committee based on the current guidelines of the Canadian Council on Animal Care (1993). Twenty-one Holstein cows $(209 \pm 53$ DIM) were first fed for ad libitum intake once per day with a TMR composed of $60.0 \%$ (DM basis) grass and legume silage, $10.0 \%$ grass hay, $9.0 \%$ rolled barley, $9.0 \%$ cracked corn, $6.7 \%$ soybean meal, $3.3 \%$ corn gluten meal, and $2.0 \%$ vitamins and minerals for a pretrial period. Cows were then divided into 7 blocks of 3 cows each according to their calving date and randomly assigned to 1 of the 3 forage types (hay and silage harvested the year before, and pasture) offered ad libitum. Regardless of the forage treatment, each cow also received and consumed $7.2 \mathrm{~kg} / \mathrm{d}$ of a concentrate mix to meet NRC nutrient requirements (NRC, 2001). The mix contained $23.3 \%$ rolled barley (DM basis), $23.3 \%$ cracked corn, $46.6 \%$ soybean meal, as well as $6.7 \%$ minerals and vitamins, and was served in 2 equal meals after a.m. (0700 h) and p.m. (1700 h) milkings. Cows had free access to water at all times during the experiment.

The experimental period lasted $27 \mathrm{~d}$. The first $21 \mathrm{~d}$ of the period were allowed for adaptation to forage treatments, and the last $6 \mathrm{~d}$ were for collection of samples and data. Cows fed hay and silage were housed in a tie-stall barn. Hay and silage were offered in 2 equal meals after each milking to provide $10 \%$ orts based on the intake on the previous day. Cows on the pasture treatment grazed together and were given access to a timothy plot on a full-time basis, except during the milking period when animals were brought back to the tie-stall barn. Pasture was allocated by strip grazing. The strip limits $(9 \times 150 \mathrm{~m})$, in the form of front and rear electrified wires placed across the plot, were moved forward to allow for a fresh provision of herbage every morning after milking.

\section{Experimental Measurements and Samplings}

The BW of cows was recorded on 3 consecutive days after the morning milking at the end of the pretrial and experimental periods. The TMR (pretrial period) as well as the hay and silage refusals (experimental period) were removed and weighed each morning after milking to determine individual intake, which was then corrected for DM based on TMR, hay, and silage samples taken twice weekly and dried in a forced-air oven at $55^{\circ} \mathrm{C}$ for $3 \mathrm{~d}$.

Pasture intake was estimated using the procedure described by Macoon et al. (2003) based on animal performance. In summary, total energy requirements were calculated by summing $\mathrm{NE}_{\mathrm{M}}, \mathrm{NE}_{\mathrm{L}}$, and net energy for BW change, walking, and grazing activity using 
the NRC equations (NRC, 2001). The $\mathrm{NE}_{\mathrm{L}}$ from forage intake was estimated as total $\mathrm{NE}_{\mathrm{L}}$ minus $\mathrm{NE}_{\mathrm{L}}$ supplied by concentrate supplement. Forage intake was finally calculated by dividing the $\mathrm{NE}_{\mathrm{L}}$ requirements from forage by its $\mathrm{NE}_{\mathrm{L}}$ content.

Samples of hay and silage offered in the barn, and grab samples of pasture from the grazed areas were randomly collected 3 times per week. These forage samples were pooled by treatment on a weekly basis, and kept frozen at $-20^{\circ} \mathrm{C}$ for further analyses. Milk yield was recorded and milk samples were collected on 6 consecutive milkings at the end of pretrial and experimental periods.

On d 25 of the experimental period, bulk milk from 2 consecutive milkings was collected separately from each group of cows and pooled by treatment in 250-L bulk tanks. Once the second milking was refrigerated $\left(4^{\circ} \mathrm{C}\right)$, milk was immediately transferred to the Laval University pilot plant (Québec, QC, Canada) to be standardized to $3.25 \%$ fat, homogenized, and pasteurized at $75^{\circ} \mathrm{C}$ for $16 \mathrm{~s}$. These processed milk samples were stored at $4^{\circ} \mathrm{C}$ in 1-L Mason glass jars to be used 7 $\mathrm{d}$ later for sensory evaluation, as described below.

\section{Feed Analyses}

Samples of hay, pasture, and silage were divided into 2 subsamples. The first set of subsamples was stored at $-20^{\circ} \mathrm{C}$ for further analyses of $\mathrm{DM}, \mathrm{CP}, \mathrm{ADF}, \mathrm{NDF}$, and ash by wet chemistry (Dairy One Laboratory, Ithaca, $\mathrm{NY}$ ). Silage samples were also analyzed for $\mathrm{pH}, \mathrm{NH}_{3^{-}}$ $\mathrm{N}$, and organic acid profile (wet chemistry; Dairy One Laboratory). The second set of subsamples was used to determine the FA profile after freeze drying and grinding through a 1-mm screen. Fatty acids were directly transesterified, and FA methyl esters were extracted following the method described by Jenkins (2010) with modifications. In the modified procedure, incubation in $3 \mathrm{~mL}$ of $\mathrm{HCl} 10 \%$ in methanol (vol/vol) was performed at $50^{\circ} \mathrm{C}$ for $30 \mathrm{~min}$ after a prior incubation in $3 \mathrm{~mL}$ of sodium methoxide $\left(0.5 \mathrm{M}\right.$ in methanol) at $70^{\circ} \mathrm{C}$ for $60 \mathrm{~min}$.

\section{Milk Analyses}

Milk samples collected from individual cows during the experiment were divided in 2 subsamples. The first set of subsamples was preserved in bronopol and stored at $4^{\circ} \mathrm{C}$ before being analyzed for SCC and concentrations of fat, true protein, and anhydrous lactose by infrared analysis with a Foss MilkoScan FT 6000 instrument (Foss Electric A/S, Hillerød, Denmark) at Valacta (Dairy Production Center of Expertise, Québec and Atlantic Provinces, Sainte-Anne-de-Bellevue, QC, Canada). The second set of subsamples from individual cows was stored at $-20^{\circ} \mathrm{C}$ without preservative until FA analysis. Before lipid extraction, milk was thawed and samples from the 6 consecutive milkings were composited proportionally to milk yield to obtain 1 sample per cow, and milk FA profiles were analyzed according to the procedure described by Boivin et al. (2013).

An additional set of composite samples from individual cows was obtained for d 25 by mixing a.m. and p.m. milk samples proportionally to milk yield. These samples were frozen $\left(-20^{\circ} \mathrm{C}\right)$ until used to determine the profile of volatile compounds. This analysis was performed in triplicate using the SPME technique. Thawed milk samples $(9.0 \mathrm{~g})$ were immediately incorporated in $20-\mathrm{mL}$ glass vials that contained $\mathrm{NaCl}(1.1$ g). Vials were sealed with silicon/Teflon septa and magnetic caps and kept at $4^{\circ} \mathrm{C}$ until analyzed the same day. Volatile compounds in milk were extracted from the headspace with a $2-\mathrm{cm}, 50 / 30-\mu \mathrm{m}$ divinylbenzene/Carboxen/polydimethylsiloxane SPME fiber (Supelco Inc., Bellefonte, PA). The analysis of volatile compounds was carried out by using a Combi PAL autosampler (CTC Analytics AG, Zwingen, Switzerland) attached to an Agilent 6890N gas chromatograph with 5973 inert mass spectrometry detection (Agilent Technologies Inc., Santa Clara, CA). The sample was preequilibrated at $55^{\circ} \mathrm{C}$ for $5 \mathrm{~min}$ with agitation at $250 \mathrm{rpm}$. The fiber was then exposed to the headspace at the same temperature and agitation for $60 \mathrm{~min}$. Once the adsorption time was finished, the volatile compounds extracted with the SPME fiber were thermally desorbed into the gas chromatograph injector in splitless mode at $255^{\circ} \mathrm{C}$ for $3 \mathrm{~min}$. Between each use, the fiber was cleaned at $270^{\circ} \mathrm{C}$ for 20 min in the Combi PAL fiber conditioning station. To avoid memory effects associated with the SPME fiber and the GC column, one sample from each dietary treatment was analyzed in triplicate each day (1 block per day). Furthermore, the injection sequence of samples from different dietary treatments was changed over the $7 \mathrm{~d}$ of analysis. Volatile compounds were separated with a DB-FFAP column $(30 \mathrm{~m} \times 0.25 \mathrm{~mm}$, 0.25- $\mu \mathrm{m}$ film thickness; Agilent Technologies Inc.). The oven temperature was held at $40^{\circ} \mathrm{C}$ for $5 \mathrm{~min}$, and then increased at a rate of $5^{\circ} \mathrm{C} / \mathrm{min}$ to $245^{\circ} \mathrm{C}$. At that point, the temperature was held at $245^{\circ} \mathrm{C}$ for 25 min. Helium was used as carrier gas at a flow rate of $0.7 \mathrm{~mL} / \mathrm{min}$.

The mass spectrometer was operated in the electron impact ionization mode at $70 \mathrm{eV}$; the mass range used was $m / z 35$ to 350 . Scan was used as the data acquisition mode. The mass spectrometer transfer line and the ion source temperatures were 255 and $230^{\circ} \mathrm{C}$, respectively. Volatile compounds were identified by comparison with mass spectra from a library database [National Institute of Standards and Technology (NIST) 08 Mass Spectral Library, version 2.0; NIST, Gaithersburg, MD) and 
confirmation of the identification of some compounds was achieved by comparing the GC retention time and mass spectra of authentic standards spiked to milk.

Standards of volatile compounds were obtained from Sigma-Aldrich (Oakville, ON, Canada; ethyl butanoate, ethyl hexanoate, acetic acid, butanoic acid, hexanoic acid, octanoic acid, decanoic acid, dodecanoic acid, tetradecanoic acid, hexadecanoic acid, hexanal, heptanal, benzaldehyde, 1-hexanol, 1-octen-3-ol, dimethyl sulfide, acetone, 2-butanone, 2-heptanone, 1-octen-3-one, 2-nonanone, 2-undecanone, $\alpha$-pinene, D-limonene, phenol, and toluene). Standards of lactones ( $\gamma$-octalactone, $\gamma$-decalactone, $\gamma$-dodecalactone, $\gamma$-dodecaenolactone, $\delta$-hexalactone, $\delta$-octalactone, $\delta$-decalactone, $\delta$-undecalactone, $\delta$-dodecalactone, $\delta$-tridecalactone, and $\delta$-tetradecalactone) were a provided courtesy of Soda Aromatic Co. Ltd. (Tokyo, Japan). A standard of $\gamma$-dodecadienolactone was kindly donated by Justin Bendall (Fonterra Research Centre, Palmerston North, New Zealand). The results were expressed as the logarithm of the area arbitrary units from selective ion-monitoring mass spectrometry of volatile compounds, as suggested by Coppa et al. (2011).

\section{Sensory Evaluation}

Processed milk samples from d 25 of the experiment were first evaluated by a panel of 30 untrained assessors, familiarized with the procedure, and recruited among laboratory staff and students to perform a triangle test (Meilgaard et al. 2007), at the Food Research and Development Centre (Saint-Hyacinthe, QC, Canada). In a first test, panelists compared the milk from cows fed hay with the milk from cows on pasture. In a second test, they compared the milk from cows fed hay with the milk from cows fed silage. A period of time had to be allotted for collection, processing, and transportation of milk. Therefore, comparisons were conducted after 7 -d storage of pasteurized milk at $4^{\circ} \mathrm{C}$. Milks were served at $7^{\circ} \mathrm{C}$ in 3 -digit-coded $100-\mathrm{mL}$ amber glass cup. A red light was used in polling booths to hide any information about the color of milk. Milk samples were also evaluated in a sensory ranking test by a similar panel. Assessors were asked to rank hay, silage, and pasture milk samples for total flavor with sensory descriptors "raw milk," "fresh milk," and "farm milk"; sweet flavor with sensory descriptors "empyreumatic," "vanilla," "caramel," and "sugar"; and grassy flavor with sensory descriptors "grass," "leafy vegetable," and "plant" on a scale of 1 to 3 (from less to more intense).

\section{Statistical Analysis}

Data were analyzed as a randomized complete block design using PROC GLIMMIX of SAS (SAS Institute
Inc., Cary, NC). Measurements obtained during the last week of the pretrial period were used as covariates for analysis of BW, forage DMI, milk yield, and milk composition data. For milk FA and milk volatile organic compounds, no covariate adjustment was performed. Milk volatile organic compounds were $\log _{10}$ transformed before statistical analysis. For both models, treatment was included as a fixed effect and block as a random effect. Tukey adjustments were performed on the effect of forage types to account for the multiple 2-way comparisons in the PROC GLIMMIX. Differences between treatments were declared at $P \leq 0.05$, and tendencies at $0.05<P<0.10$.

Statistical analyses for data regarding sensory evaluation were performed with Fizz (Sensory Analysis and Consumer Test Management Software, version 2.0a; Biosystèmes, Couternon, France). For the triangle test for difference, data were analyzed by counting the number of correct responses (correctly identified "different" sample) and the number of total responses. These numbers were compared with critical values as described by Meilgaard et al. (2007) to determine significant differences. For the difference test, parameters were defined at $n=30, \alpha$ (risk of concluding that a perceptible difference exists when it does not) $=$ $0.01, \beta$ (concluding that no perceptible difference exists when one does $)=0.10$, and $\mathrm{Pd}$ (maximum allowable proportion of distinguishers $)=50 \%$. For the ranking test, PROC FREQ (SAS Institute Inc.) was used to generate Cochran-Mantel-Haenszel statistics, with significance tested using Friedman's $\chi^{2}$ at $P<0.05$, to determine whether milk from one treatment differed from the others. Least squares means were calculated for each family of volatile compounds and each treatment from the ANOVA.

A principal components analysis was performed on these means using PROC PRINCOMP (SAS Institute Inc.) to assess the relationships among families of volatile compounds in milk and how variations in these variates were related to forage type fed to the cows. The contribution of each variate to a principal component axis can be seen from its score (Figure 1).

\section{RESULTS AND DISCUSSION}

Forage concentrations of $\mathrm{CP}$ and total FA were higher in pasture, intermediate in silage, and lower in hay (Table 1). The opposite observation could be made for NDF concentration, with the highest and the lowest concentrations measured in hay and pasture, respectively, and silage being intermediate. Similar conclusions were reported previously (Martineau et al., 2007; Mohammed et al., 2009) when chemical compositions of hay, pasture, and silage were compared. Tedding 


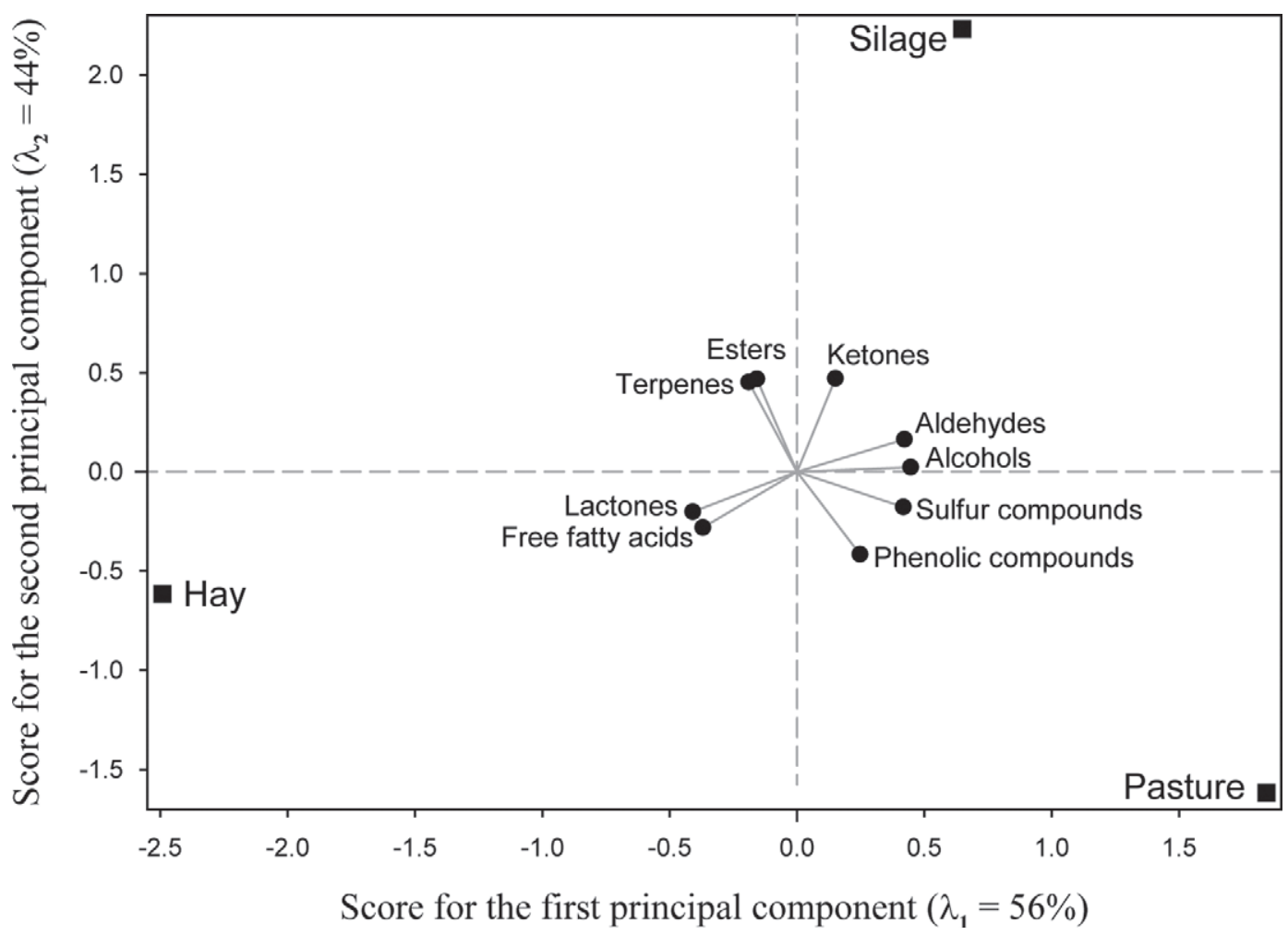

Figure 1. Diagram of the 2 principal component scores calculated for the 3 timothy forage types ( $)$ and for each family of volatile organic compounds found in the milk $(\bullet)$ to illustrate how the timothy forage type fed to the cows affected esters, FFA, aldehydes, alcohols, sulfur compounds, ketones, lactones, terpenes, and phenolic compounds in milk. $\lambda=$ percentage of the covariation described by the first $\left(\lambda_{1}\right)$ and second $\left(\lambda_{2}\right)$ principal components.

and raking are known to cause leaf losses, which may explain the higher concentration of NDF and the lower concentrations of $\mathrm{CP}$ and total FA in hay than in silage and pasture of the current trial. In contrast, more leaves were harvested when grab samples of herbage were collected from the timothy pasture plots. Such samples should represent the material that the cows were selecting while grazing (Mohammed et al., 2009) and explained the better nutritive value of this forage type. Finally, harvesting forage as silage is known to minimize leaf losses compared with hay making. However, the whole timothy plant (leaves and stems) was harvested, which may explain the intermediate $\mathrm{CP}, \mathrm{FA}$, and NDF concentrations obtained for silage compared with hay and pasture. The silage produced was of good quality, as shown by its $\mathrm{pH}$ of 4.2 and its organic acid profile dominated by lactic and acetic acids (data not shown).

When expressed as a percentage by weight of total FA, hay contained less cis-9,cis-12,cis-15 18:3 ( $\alpha$-linolenic acid) and more 16:0 (palmitic acid) compared with pasture or silage (Table 1). This is consistent with the observations of Demir and Çakmak (2007) who reported less PUFA and more SFA in stems than in leaves in different subspecies of Medicago.

Final BW and BW change over the 27-d experimental period were higher for cows fed silage, intermediate for those fed hay, and lower for cows on pasture (Table 2). Measured forage DMI represented, on average, $66 \%$ of total DMI and it was not different between cows fed hay or silage (Table 2). Calculated forage DMI, as estimated based on animal performances, were 5 and $3 \%$ higher than the measured values of forage DMI for cows fed hay and silage, respectively (Table 2). Pasture intake calculated following the same procedure, and including walking and grazing activities, gave an estimate of $13.5 \mathrm{~kg} / \mathrm{d}$, which is similar to the measured forage DMI of cows fed hay and silage. The lack of difference in DMI between cows fed hay and silage in the current trial is consistent with data reported by Martineau et al. (2007) when comparing timothy hay with timothy silage treated with formic acid or inoculated with lactic acid bacteria. In contrast, Shingfield et al. (2005) observed a higher forage intake when feeding grass silage compared with hay, whereas Broderick (1995) observed a lower intake of alfalfa silage as compared with hay in 
Table 1. Chemical composition of the 3 experimental timothy forage types ${ }^{1}$

\begin{tabular}{|c|c|c|c|}
\hline \multirow[b]{2}{*}{ Item } & \multicolumn{3}{|c|}{ Timothy forage type } \\
\hline & Hay & Pasture & Silage \\
\hline DM, \% & $91.6(1.4)$ & $22.2(1.6)$ & $37.5(2.7)$ \\
\hline OM. $\%$ of DM & $93.4(0.3)$ & $92.6(1.0)$ & $92.0(0.2)$ \\
\hline $\mathrm{CP}, \%$ of $\mathrm{DM}$ & $9.0(0.5)$ & $12.7(1.2)$ & $11.2(0.3)$ \\
\hline $\mathrm{NDF}, \%$ of DM & $67.4(3.3)$ & $58.6(6.5)$ & $62.4(3.5)$ \\
\hline $\mathrm{ADF}, \%$ of $\mathrm{DM}$ & $38.0(1.6)$ & $33.3(3.7)$ & $38.9(0.6)$ \\
\hline $\mathrm{NE}_{\mathrm{L}}{ }^{2}$ & $1.06(0.07)$ & $1.30(0.13)$ & $1.20(0.06)$ \\
\hline \multicolumn{4}{|l|}{$\mathrm{FA}, \mathrm{mg} / \mathrm{g}$ of $\mathrm{DM}$} \\
\hline $14: 0$ & $0.07(0.01)$ & $0.12(0.02)$ & $0.11(0.01)$ \\
\hline $16: 0$ & $1.90(0.13)$ & $3.20(0.34)$ & $2.44(0.12)$ \\
\hline cis-9 16:1 & $0.033(0.007)$ & $0.058(0.020)$ & $0.045(0.003)$ \\
\hline $18: 0$ & $0.18(0.02)$ & $0.35(0.05)$ & $0.24(0.01)$ \\
\hline cis-9 18:1 & $0.37(0.01)$ & $0.96(0.36)$ & $0.48(0.01)$ \\
\hline cis-11 $18: 1$ & $0.05(0.01)$ & $0.10(0.02)$ & $0.08(0.01)$ \\
\hline cis-9,cis-12 18:2 & $1.92(0.10)$ & $4.02(1.25)$ & $2.69(0.07)$ \\
\hline $20: 0$ & $0.10(0.01)$ & $0.20(0.02)$ & $0.12(0.01)$ \\
\hline cis-9,cis-12,cis-15 18:3 & $3.46(0.68)$ & $7.55(0.37)$ & $6.49(0.31)$ \\
\hline Total FA & $8.08(0.93)$ & $16.56(2.38)$ & $12.68(0.51)$ \\
\hline \multicolumn{4}{|l|}{ FA, $\%$ by weight } \\
\hline 14:0 & $0.90(0.07)$ & $0.74(0.04)$ & $0.85(0.06)$ \\
\hline $16: 0$ & $23.6(1.2)$ & $19.6(0.9)$ & $19.22(0.14)$ \\
\hline cis-9 16:1 & $0.41(0.05)$ & $0.34(0.07)$ & $0.35(0.03)$ \\
\hline $18: 0$ & $2.3(0.2)$ & $2.1(0.1)$ & $1.9(0.1)$ \\
\hline cis-9 18:1 & $4.7(0.6)$ & $5.5(1.30)$ & $3.8(0.2)$ \\
\hline cis-11 18:1 & $0.60(0.02)$ & $0.63(0.10)$ & $0.65(0.04)$ \\
\hline cis-9,cis-12 $18: 2$ & $23.9(1.8)$ & $23.4(4.0)$ & $21.2(0.6)$ \\
\hline 20:0 & $1.19(0.03)$ & $1.24(0.17)$ & $0.92(0.04)$ \\
\hline cis-9,cis- 12, cis-15 18:3 & $42.5(3.6)$ & $46.4(4.4)$ & $51.1(0.6)$ \\
\hline
\end{tabular}

${ }^{1}$ The data reported are the means (SD) of 4 composite forage samples pooled by treatments on a weekly basis over the experimental period.

${ }^{2}$ Calculated according to NRC (2001).

2 consecutive trials using alfalfa as sole forage in the diets.

Actual milk yield was higher for cows on pasture, intermediate for cows fed silage, and lower for cows fed hay (Table 2). However, milk fat content was higher for cows fed hay and silage compared with cows on pasture. As a result, FCM and fat yield were not different between treatments. Milk protein and anhydrous lactose contents and yields were also similar among treatments.

Cows on pasture required more energy for walking and grazing activities but were able to maintain similar FCM compared with cows fed hay or silage. However, these former cows had to mobilize body reserves, as they lost $10.5 \mathrm{~kg}$, on average, whereas cows fed hay and silage gained 5.4 and $20.3 \mathrm{~kg}$, respectively, over the $27-\mathrm{d}$ experimental period.

Mohammed et al. (2009) reported higher production of milk and milk constituents (fat, protein, and lactose) for cows on pasture compared with cows fed grass silage. In their study, however, grass silage was harvested at a more advanced stage of development and was of lower nutritive value than pasture grass, as opposed to the current experiment where data collection on cows fed pasture was planned when timothy reached the late heading stage, which is the same stage of development at harvest of timothy fed as hay and silage. Similarly, Keady et al. (1996) compared zero-grazed grass with grass silage harvested at a similar stage of development, and also reported higher production of milk and milk constituents for cows receiving the zero-grazed grass.

Lack of difference in milk yield and fat content between cows fed hay and silage in the current study is consistent with data reported by Martineau et al. (2007) and Shingfield et al. (2005) using grass forages. In contrast, Broderick (1995) conducted 2 trials comparing alfalfa hay and silage, and observed similar milk yield in a first experiment and higher milk yield with alfalfa hay in a second experiment.

Concentrations of cis-9,cis-12 18:2 (linoleic acid) and cis-9,cis-12,cis-15 18:3 were 2-fold higher in timothy pasture than hay, and intermediate in timothy silage (Table 1). Increasing the supply of dietary cis-9, cis-12 18:2 and cis-9,cis-12,cis-15 18:3 when feeding pasture significantly enhanced the concentration of these 2 essential FA in milk fat compared with feeding hay or silage (Table 3). Feeding pasture also increased milk fat content of FA (Table 3) that are intermediate in 
Table 2. Body weight, forage intake, milk yield, and milk composition in Holstein cows fed timothy hay, pasture, or silage

\begin{tabular}{|c|c|c|c|c|c|}
\hline \multirow[b]{2}{*}{ Item } & \multicolumn{3}{|c|}{ Timothy forage type } & \multirow[b]{2}{*}{$\mathrm{SEM}^{1}$} & \multirow[b]{2}{*}{$P$-value } \\
\hline & Hay & Pasture & Silage & & \\
\hline \multicolumn{6}{|l|}{ BW } \\
\hline Actual, kg & $640^{\mathrm{ab}}$ & $626^{\mathrm{b}}$ & $657^{\mathrm{a}}$ & 5 & $<0.01$ \\
\hline Change, ${ }^{2} \mathrm{~kg} / \mathrm{d}$ & $0.20^{\mathrm{ab}}$ & $-0.39^{\mathrm{b}}$ & $0.75^{\mathrm{a}}$ & 0.18 & $<0.01$ \\
\hline \multicolumn{6}{|l|}{ Forage DMI } \\
\hline Measured, $\mathrm{kg} / \mathrm{d}$ & 13.0 & - & 14.5 & 0.8 & 0.24 \\
\hline Calculated, ${ }^{3} \mathrm{~kg} / \mathrm{d}$ & 13.7 & 13.5 & 15.0 & - & - \\
\hline \multicolumn{6}{|l|}{ Milk yield } \\
\hline Actual, kg/d & $23.3^{\mathrm{b}}$ & $26.7^{\mathrm{a}}$ & $24.0^{\mathrm{ab}}$ & 1.0 & 0.05 \\
\hline Fat-corrected, ${ }^{4} \mathrm{~kg} / \mathrm{d}$ & 24.3 & 26.2 & 25.3 & 1.0 & 0.40 \\
\hline \multicolumn{6}{|l|}{ Milk fat, } \\
\hline Content, \% & $4.31^{\mathrm{a}}$ & $3.89^{\mathrm{b}}$ & $4.46^{\mathrm{a}}$ & 0.11 & $<0.01$ \\
\hline Yield, g/d & 999 & 1,033 & 1,051 & 39 & 0.63 \\
\hline \multicolumn{6}{|l|}{ Milk true protein } \\
\hline Content, \% & 3.36 & 3.26 & 3.32 & 0.04 & 0.23 \\
\hline Yield, g/d & 771 & 864 & 798 & 35 & 0.12 \\
\hline \multicolumn{6}{|l|}{ Milk anhydrous lactose } \\
\hline Content, \% & 4.54 & 4.55 & 4.55 & 0.03 & 0.92 \\
\hline Yield, g/d & 1,063 & 1,213 & 1,086 & 51 & 0.11 \\
\hline $\mathrm{SCC}, \times 1,000$ cells $/ \mathrm{mL}$ & 78 & 79 & 89 & 49 & 0.99 \\
\hline
\end{tabular}

${ }^{\mathrm{a}, \mathrm{b}}$ Within a row, mean values followed by different superscripts are different $(P \leq 0.05)$.

${ }^{1}$ Standard error of the mean for 7 measurements.

${ }^{2}$ Over $27 \mathrm{~d}$ of the experimental period.

${ }^{3}$ Calculated based on animal performances by computing $\mathrm{NE}_{\mathrm{M}}, \mathrm{NE}_{\mathrm{L}}$, and net energy for $\mathrm{BW}$ change, walking, and grazing activities for cows on pasture according to Macoon et al. (2003).

${ }^{4} 4 \% \mathrm{FCM}=[0.4 \times$ milk $(\mathrm{kg} / \mathrm{d})]+[15.0 \times$ fat $(\mathrm{kg} / \mathrm{d})]$.

ruminal biohydrogenation of cis-9,cis-12 18:2 (e.g., cis-9,trans-11 18:2 and trans-11 18:1) and cis-9, cis12,cis-15 18:3 (cis-9,trans-11,cis-15 18:3, trans-11, cis-15 18:2, and trans-11 18:1). Milk fat content of 18:0 (stearic acid), which is the final common product of the biohydrogenation processes, was also increased when cows were on pasture.

Milk fat content of cis-9,cis-12,cis-15 18:3 was significantly lower for cows fed silage than for cows fed hay, even though the cis-9,cis-12,cis-15 18:3 forage concentration was almost 2 times higher in silage compared with hay. This result is consistent with observations reported by Boufaied et al. (2003), showing that even if hay making reduced the concentration of cis-9, cis12,cis-15 18:3 in forage DM compared with silage, a slower rate of in vitro disappearance and a greater ruminal bypass of this FA was observed with hay than with silage. According to these results (Boufaïed et al., 2003), timothy conserved as hay would maximize the proportion of cis-9,cis-12,cis-15 18:3 potentially escaping ruminal biohydrogenation. In the current trial, a possible lower transfer efficiency with silage compared with hay led to the accumulation of more biohydrogenation intermediates in milk fat.

According to O'Brien (2008), a greasy mouth feel could be detected in imitation milk when the melting point of emulsified lipids is too high, which affect the in-mouth perception of fat globules. In this regard, 16:0 (melting point: $62.9^{\circ} \mathrm{C}$ ) and cis-9 18:1 (oleic acid; melting point: $13-14^{\circ} \mathrm{C}$ ) are the 2 most abundant $\mathrm{FA}$ in milk fat and they were used by Couvreur et al. (2006) to define a spreadability index. In the current study, the concentration of 16:0 in milk fat was higher for cows fed hay and silage than for those on pasture (Table 3). In contrast, the milk fat concentration of cis-9 18:1 was higher for cows on pasture, intermediate for cows fed silage, and lower for those fed hay $(P=0.06)$. As a result, the ratio of 16:0 to cis-9 18:1 in milk fat was lower for cows on pasture compared with the other 2 forage types (Table 3). These modifications on milk FA profile could potentially affect the textural properties of butter obtained from this milk. Indeed, a reduction in the 16:0-to-cis-9 18:1 ratio in milk fat has previously been reported when increasing the proportion of fresh grass in the cow diet (Couvreur et al., 2006) or by replacing corn silage with hay (Hurtaud et al., 2007). In both of these trials, reducing the 16:0-to-cis-9 18:1 ratio in milk fat was associated with a perception of less firmness and more melting in the mouth by a sensory analysis panel.

Fifty different volatile compounds were identified and quantified in individual milk samples (Table 4). Total levels of milk volatile organic compounds were similar among treatments (data not shown; $P=0.23$ ). These 
Table 3. Effect of forage type on milk FA profile in Holstein cows

\begin{tabular}{|c|c|c|c|c|c|}
\hline \multirow[b]{2}{*}{ FA, $\%$ by weight } & \multicolumn{3}{|c|}{ Timothy forage type } & \multirow[b]{2}{*}{ SEM $^{1}$} & \multirow[b]{2}{*}{$P$-value } \\
\hline & Hay & Pasture & Silage & & \\
\hline 4:0 & 5.006 & 5.038 & 4.935 & 0.112 & 0.72 \\
\hline $6: 0$ & 2.588 & 2.472 & 2.459 & 0.081 & 0.49 \\
\hline $8: 0$ & 1.308 & 1.264 & 1.269 & 0.057 & 0.83 \\
\hline 10:0 & 2.912 & 2.650 & 2.763 & 0.162 & 0.53 \\
\hline cis-9 10:1 & 0.331 & 0.288 & 0.321 & 0.023 & 0.33 \\
\hline 11:0 & 0.042 & 0.035 & 0.049 & 0.007 & 0.34 \\
\hline $12: 0$ & 3.391 & 2.914 & 3.206 & 0.201 & 0.28 \\
\hline cis-9 12:1 & 0.104 & 0.084 & 0.098 & 0.008 & 0.21 \\
\hline iso $13: 0$ & $0.038^{\mathrm{ab}}$ & $0.046^{\mathrm{a}}$ & $0.032^{\mathrm{b}}$ & 0.003 & 0.02 \\
\hline anteiso 13:0 & 0.019 & 0.021 & 0.017 & 0.004 & 0.67 \\
\hline $13: 0$ & 0.082 & 0.069 & 0.092 & 0.009 & 0.22 \\
\hline iso $14: 0$ & $0.138^{\mathrm{a}}$ & $0.130^{\mathrm{a}}$ & $0.098^{\mathrm{b}}$ & 0.009 & $<0.01$ \\
\hline 14:0 & $12.203^{\mathrm{y}}$ & $10.664^{\mathrm{z}}$ & $11.711^{\mathrm{yz}}$ & 0.461 & 0.09 \\
\hline cis-9 14:1 & $1.215^{\mathrm{a}}$ & $0.975^{\mathrm{b}}$ & $1.260^{\mathrm{a}}$ & 0.070 & 0.02 \\
\hline cis-11 14:1 & 0.047 & 0.040 & 0.044 & 0.003 & 0.36 \\
\hline iso $15: 0$ & $0.346^{\mathrm{y}}$ & $0.306^{\mathrm{yz}}$ & $0.261^{\mathrm{z}}$ & 0.023 & 0.07 \\
\hline anteiso $15: 0$ & 0.607 & 0.589 & 0.487 & 0.043 & 0.15 \\
\hline $15: 0$ & 1.107 & 1.054 & 1.156 & 0.081 & 0.66 \\
\hline iso $16: 0$ & $0.245^{\mathrm{a}}$ & $0.233^{\mathrm{a}}$ & $0.188^{\mathrm{b}}$ & 0.013 & $<0.01$ \\
\hline 16:0 & $37.820^{\mathrm{a}}$ & $29.338^{\mathrm{b}}$ & $36.348^{\mathrm{a}}$ & 1.317 & $<0.01$ \\
\hline trans-9 16:1 & 0.198 & 0.095 & 0.058 & 0.045 & 0.12 \\
\hline iso $17: 0^{2}$ & $0.269^{\mathrm{b}}$ & $0.423^{\mathrm{a}}$ & $0.319^{\mathrm{ab}}$ & 0.030 & $<0.01$ \\
\hline cis-9 16:1 & 1.564 & 1.624 & 1.880 & 0.120 & 0.18 \\
\hline anteiso $17: 0^{3}$ & $0.554^{\mathrm{a}}$ & $0.547^{\mathrm{a}}$ & $0.462^{\mathrm{b}}$ & 0.019 & $<0.01$ \\
\hline cis-11 16:1 & 0.037 & 0.047 & 0.049 & 0.009 & 0.58 \\
\hline cis-13 16:1 & $0.204^{\mathrm{a}}$ & $0.138^{\mathrm{b}}$ & $0.182^{\mathrm{ab}}$ & 0.014 & 0.02 \\
\hline 17:0 & $0.542^{\mathrm{a}}$ & $0.556^{\mathrm{a}}$ & $0.494^{\mathrm{b}}$ & 0.011 & $<0.01$ \\
\hline cis-7 17:1 & 0.023 & 0.024 & 0.028 & 0.002 & 0.22 \\
\hline cis-8 17:1 & 0.051 & 0.045 & 0.056 & 0.004 & 0.25 \\
\hline cis-9 17:1 & 0.211 & 0.255 & 0.223 & 0.016 & 0.17 \\
\hline iso $18: 0$ & 0.066 & 0.053 & 0.056 & 0.004 & 0.12 \\
\hline $18: 0$ & $7.144^{\mathrm{b}}$ & $8.980^{\mathrm{a}}$ & $7.233^{\mathrm{b}}$ & 0.448 & 0.01 \\
\hline trans-4 18:1 & $0.007^{\mathrm{b}}$ & $0.012^{\mathrm{a}}$ & $0.008^{\mathrm{b}}$ & 0.001 & $<0.01$ \\
\hline trans -5 18:1 & $0.007^{\mathrm{b}}$ & $0.012^{\mathrm{a}}$ & $0.009^{\mathrm{ab}}$ & 0.001 & $<0.01$ \\
\hline trans-6-8 18:1 & $0.114^{\mathrm{b}}$ & $0.164^{\mathrm{a}}$ & $0.123^{\mathrm{b}}$ & 0.008 & $<0.01$ \\
\hline trans-9 18:1 & $0.081^{\mathrm{b}}$ & $0.130^{\mathrm{a}}$ & $0.093^{\mathrm{b}}$ & 0.006 & $<0.01$ \\
\hline trans-10 18:1 & $0.086^{\mathrm{b}}$ & $0.200^{\mathrm{a}}$ & $0.112^{\mathrm{b}}$ & 0.009 & $<0.01$ \\
\hline trans-11 18:1 & $0.573^{\mathrm{c}}$ & $1.690^{\mathrm{a}}$ & $1.009^{\mathrm{b}}$ & 0.088 & $<0.01$ \\
\hline trans-12 18:1 & $0.072^{\mathrm{c}}$ & $0.194^{\mathrm{a}}$ & $0.105^{\mathrm{b}}$ & 0.006 & $<0.01$ \\
\hline trans-13/14 18:1 & $0.113^{\mathrm{c}}$ & $0.349^{\mathrm{a}}$ & $0.200^{\mathrm{b}}$ & 0.016 & $<0.01$ \\
\hline trans-15 18:1 & $0.181^{\mathrm{b}}$ & $0.317^{\mathrm{a}}$ & $0.255^{\mathrm{ab}}$ & 0.032 & 0.03 \\
\hline trans-16 18:1 & $0.068^{\mathrm{b}}$ & $0.186^{\mathrm{a}}$ & $0.109^{\mathrm{b}}$ & 0.012 & $<0.01$ \\
\hline cis-6-8 18:1 & $0.061^{\mathrm{a}}$ & $0.027^{\mathrm{b}}$ & $0.060^{\mathrm{a}}$ & 0.008 & 0.02 \\
\hline cis-9 $18: 1^{4}$ & $13.921^{\mathrm{z}}$ & $19.523^{\mathrm{y}}$ & $15.731^{\mathrm{yz}}$ & 1.536 & 0.06 \\
\hline cis-11 18:1 & $0.443^{\mathrm{z}}$ & $0.695^{\mathrm{y}}$ & $0.435^{\mathrm{z}}$ & 0.082 & 0.07 \\
\hline cis-12 18:1 & $0.072^{\mathrm{b}}$ & $0.113^{\mathrm{a}}$ & $0.061^{\mathrm{b}}$ & 0.010 & $<0.01$ \\
\hline cis-13 18:1 & 0.042 & 0.059 & 0.045 & 0.012 & 0.58 \\
\hline cis-14 18:1 & $0.023^{\mathrm{c}}$ & $0.042^{\mathrm{a}}$ & $0.030^{\mathrm{b}}$ & 0.002 & $<0.01$ \\
\hline cis-15 18:1 & 0.040 & 0.047 & 0.051 & 0.004 & 0.22 \\
\hline cis-9, cis-12 18:2 & $1.211^{\mathrm{b}}$ & $1.616^{\mathrm{a}}$ & $1.031^{\mathrm{b}}$ & 0.094 & $<0.01$ \\
\hline cis-9,trans-11 18:2 & $0.278^{\mathrm{b}}$ & $0.837^{\mathrm{a}}$ & $0.525^{\mathrm{b}}$ & 0.076 & $<0.01$ \\
\hline cis-9,trans-12 18:2 & $0.012^{\mathrm{c}}$ & $0.023^{\mathrm{a}}$ & $0.018^{\mathrm{b}}$ & 0.002 & $<0.01$ \\
\hline cis-9,trans-13 18:2 & $0.071^{\mathrm{b}}$ & $0.106^{\mathrm{a}}$ & $0.077^{\mathrm{b}}$ & 0.004 & $<0.01$ \\
\hline trans-8, cis-12 18:2 & $0.081^{\mathrm{b}}$ & $0.149^{\mathrm{a}}$ & $0.103^{\mathrm{b}}$ & 0.007 & $<0.01$ \\
\hline trans-8, cis-13 18:2 & $0.034^{\mathrm{b}}$ & $0.075^{\mathrm{a}}$ & $0.048^{\mathrm{b}}$ & 0.005 & $<0.01$ \\
\hline trans -9, trans $-12 \quad 18: 2$ & $0.008^{\mathrm{b}}$ & $0.026^{\mathrm{a}}$ & $0.021^{\mathrm{a}}$ & 0.003 & $<0.01$ \\
\hline trans-9,cis-12 18:2 & $0.018^{\mathrm{b}}$ & $0.036^{\mathrm{a}}$ & $0.022^{\mathrm{b}}$ & 0.002 & $<0.01$ \\
\hline trans-10,cis-12 18:2 & $0.024^{\mathrm{b}}$ & $0.033^{\mathrm{a}}$ & $0.024^{\mathrm{b}}$ & 0.001 & $<0.01$ \\
\hline trans-11,cis-15 18:2 & $0.050^{\mathrm{c}}$ & $0.178^{\mathrm{a}}$ & $0.117^{\mathrm{b}}$ & 0.013 & $<0.01$ \\
\hline cis-9,trans-11,cis-15 18:3 & $0.022^{\mathrm{b}}$ & $0.031^{\mathrm{a}}$ & $0.030^{\mathrm{a}}$ & 0.003 & 0.02 \\
\hline cis-6, cis-9,cis-12 18:3 & 0.027 & 0.031 & 0.027 & 0.003 & 0.48 \\
\hline cis-9,cis-12,cis-15 18:3 & $0.403^{\mathrm{b}}$ & $0.568^{\mathrm{a}}$ & $0.323^{\mathrm{c}}$ & 0.024 & $<0.01$ \\
\hline cis-6,cis-9,cis-12,cis-15 18:4 & 0.013 & 0.017 & 0.014 & 0.002 & 0.29 \\
\hline
\end{tabular}


Table 3 (Continued). Effect of forage type on milk FA profile in Holstein cows

\begin{tabular}{|c|c|c|c|c|c|}
\hline \multirow[b]{2}{*}{ FA, \% by weight } & \multicolumn{3}{|c|}{ Timothy forage type } & \multirow[b]{2}{*}{$\mathrm{SEM}^{1}$} & \multirow[b]{2}{*}{$P$-value } \\
\hline & Hay & Pasture & Silage & & \\
\hline 19:0 & 0.035 & 0.043 & 0.031 & 0.004 & 0.10 \\
\hline 20:0 & 0.144 & 0.150 & 0.144 & 0.005 & 0.58 \\
\hline cis-9 20:1 & 0.105 & 0.110 & 0.108 & 0.005 & 0.84 \\
\hline cis-11 20:1 & 0.026 & 0.033 & 0.029 & 0.004 & 0.42 \\
\hline cis-11,cis-14 20:2 & 0.026 & 0.028 & 0.026 & 0.002 & 0.46 \\
\hline cis-11, cis-14, cis-17 20:3 & 0.008 & 0.010 & 0.008 & 0.001 & 0.12 \\
\hline cis-8, cis-11, cis-14 20:3 & $0.064^{\mathrm{b}}$ & $0.081^{\mathrm{a}}$ & $0.062^{\mathrm{b}}$ & 0.004 & $<0.01$ \\
\hline cis-5,cis-8,cis-11,cis-14 20:4 & $0.103^{\mathrm{a}}$ & $0.106^{\mathrm{a}}$ & $0.089^{\mathrm{b}}$ & 0.005 & $<0.01$ \\
\hline cis-8,cis-11,cis-14,cis-17 20:4 & 0.004 & 0.006 & 0.005 & 0.001 & 0.57 \\
\hline cis-5,cis-8,cis-11,cis-14,cis-17 20:5 & $0.041^{\mathrm{ab}}$ & $0.048^{\mathrm{a}}$ & $0.035^{\mathrm{b}}$ & 0.002 & $<0.01$ \\
\hline $22: 0$ & 0.655 & 0.692 & 0.600 & 0.040 & 0.29 \\
\hline cis-13 22:1 & 0.010 & 0.008 & 0.008 & 0.001 & 0.39 \\
\hline cis-13,cis-16 22:2 & 0.051 & 0.043 & 0.056 & 0.004 & 0.14 \\
\hline cis-13,cis-16,cis-19 22:3 & 0.005 & 0.007 & 0.005 & 0.001 & 0.23 \\
\hline cis-7,cis-10,cis-13,cis-16 22:4 & 0.021 & 0.019 & 0.021 & 0.002 & 0.67 \\
\hline cis-4,cis-7,cis-10,cis-13,cis-16 22:5 & 0.008 & 0.007 & 0.008 & 0.001 & 0.67 \\
\hline cis- 7, cis- 10, cis- 13, cis- 16, cis-19 22:5 & $0.061^{\mathrm{b}}$ & $0.071^{\mathrm{a}}$ & $0.053^{\mathrm{b}}$ & 0.003 & $<0.01$ \\
\hline cis-4,cis-7,cis-10,cis-13,cis-16,cis-19 22:6 & 0.007 & 0.006 & 0.007 & 0.001 & 0.56 \\
\hline $24: 0$ & $0.043^{\mathrm{ab}}$ & $0.048^{\mathrm{a}}$ & $0.038^{\mathrm{b}}$ & 0.003 & 0.04 \\
\hline cis-9 24:1 & 0.020 & 0.017 & 0.019 & 0.002 & 0.58 \\
\hline 16:0:cis-9 18:1 ratio & $2.803^{\mathrm{a}}$ & $1.556^{\mathrm{b}}$ & $2.567^{\mathrm{a}}$ & 0.243 & $<0.01$ \\
\hline \multicolumn{6}{|c|}{$\overline{\mathrm{a}-\mathrm{c}}$ Within a row, mean values followed by different superscripts are different $(P \leq 0.05)$. } \\
\hline \multicolumn{6}{|c|}{${ }^{\mathrm{y}, \mathrm{z}}$ Within a row, mean values followed by different superscripts are different $(0.05<P<0.10)$} \\
\hline \multicolumn{6}{|c|}{${ }^{1}$ Standard error of the mean for 7 measurements. } \\
\hline \multicolumn{6}{|c|}{${ }^{2}$ Coelution with a minor concentration of trans-10 16:1. } \\
\hline \multicolumn{6}{|c|}{${ }^{3}$ Coelution with a minor concentration of cis-10 16:1. } \\
\hline${ }^{4}$ Coelution with a minor concentration of & & & & & \\
\hline
\end{tabular}

molecules were grouped in 9 different families, including esters, FFA, aldehydes, alcohols, sulfur compounds, ketones, lactones, terpenes, and phenolic compounds. The principal components analysis biplot of the individual families of volatile compounds demonstrates variations between milk from cows fed different forage types (Figure 1). Milk from cows fed hay was characterized by higher contents of FFA and lactones. In contrast, milk from cows on pasture was enriched in phenolic and sulfur compounds as well as aldehydes and alcohols. Milk from cows fed silage presented higher concentrations of ketones.

The contents of volatile FFA with chain length of 4 (butanoic acid) to 14 (tetradecanoic acid) carbons were higher in milk from cows fed hay, intermediate in milk from cows fed pasture, and lower in milk from cows fed silage (Table 4). These variations did not seem to be related to milk fat concentration, as cows fed silage had the highest value for this parameter. The presence of FFA in milk can be explained by (1) an incomplete esterification in the mammary gland before lipid secretion (Marsili, 2003), a phenomenon that is not well documented, or (2) lipid hydrolysis that occurred during storage after milking. Spontaneous lipolysis in stored milk is partly due to the action of the enzyme lipoprotein lipase (Santos et al., 2003).
Variations in FFA content of milk observed in the current trial are in contradiction with the study conducted by Chazal et al. (1987), where grass silage feeding enhanced FFA concentration in milk compared with pasture or hay, whereas no difference was observed between these latter 2 forage treatments. However, it has been reported that feeding cows with high dietary levels of PUFA decreases milk fat lipolysis, whereas 16:0 feeding increases this reaction (Chilliard, 1982). This observation seems to be consistent with the results of the current study where cows fed hay had the lowest supply of dietary PUFA (Table 1) and the highest concentration of milk FFA (Table 4).

Pentanal and 1-pentanol were detected with more intensity in milk from cows fed pasture and silage than in milk from cows fed hay (Table 4). Straight-chain aldehydes such as pentanal can derive from lipid degradation (Toso et al., 2002). In particular, pentanal is a product of the autoxidation of PUFA from the n- 6 family, such as cis-9,cis-12 18:2 (Belitz et al., 2009).

Forage concentration of cis-9,cis-12 18:2 was greater in pasture and silage than hay (Table 1). Moreover, milk from cows on pasture had a greater concentration of cis-9,cis-12 18:2 compared with milk from cows fed hay (Table 3). These observations may explain the increase in milk pentanal for pasture-fed cows. No obvi- 
Table 4. Contents of individual milk volatile organic compounds in Holstein cows fed timothy as hay, pasture, or silage ${ }^{1}$

\begin{tabular}{|c|c|c|c|c|c|}
\hline \multirow[b]{2}{*}{ Item } & \multicolumn{3}{|c|}{ Timothy forage type } & \multirow[b]{2}{*}{$\mathrm{SEM}^{2}$} & \multirow[b]{2}{*}{$P$-value } \\
\hline & Hay & Pasture & Silage & & \\
\hline \multicolumn{6}{|l|}{ Ester } \\
\hline Ethyl butanoate & 3.22 & 3.30 & 4.12 & 0.45 & 0.17 \\
\hline Ethyl hexanoate & 3.20 & 2.57 & 3.54 & 0.60 & 0.41 \\
\hline Methyl butanoate & 4.40 & 4.49 & 4.23 & 0.14 & 0.39 \\
\hline Methyl hexanoate & 4.98 & 5.06 & 4.72 & 0.14 & 0.21 \\
\hline Methyl octanoate & 4.93 & 4.98 & 4.62 & 0.15 & 0.24 \\
\hline Methyl decanoate & 4.51 & 4.53 & 4.24 & 0.16 & 0.36 \\
\hline \multicolumn{6}{|l|}{ FFA } \\
\hline Acetic acid (2:0) & 4.80 & 4.78 & 4.66 & 0.07 & 0.31 \\
\hline Butanoic acid (4:0) & $6.08^{\mathrm{y}}$ & $5.78^{\mathrm{yz}}$ & $5.68^{\mathrm{z}}$ & 0.13 & 0.07 \\
\hline Hexanoic acid $(6: 0)$ & $6.61^{\mathrm{a}}$ & $6.31^{\mathrm{ab}}$ & $6.16^{\mathrm{b}}$ & 0.13 & 0.05 \\
\hline Octanoic acid $(8: 0)$ & $6.61^{\mathrm{a}}$ & $6.32^{\mathrm{ab}}$ & $6.12^{\mathrm{b}}$ & 0.14 & 0.05 \\
\hline Decanoic acid $(10: 0)$ & $6.38^{\mathrm{a}}$ & $6.07^{\mathrm{ab}}$ & $5.87^{\mathrm{b}}$ & 0.14 & 0.06 \\
\hline Dodecanoic acid (12:0) & $5.39^{\mathrm{y}}$ & $5.04^{\mathrm{yz}}$ & $4.88^{\mathrm{z}}$ & 0.15 & 0.07 \\
\hline Tetradecanoic acid (14:0) & $4.58^{\mathrm{y}}$ & $4.29^{\mathrm{yz}}$ & $4.21^{\mathrm{z}}$ & 0.13 & 0.10 \\
\hline Hexadecanoic acid (16:0) & 3.86 & 3.65 & 3.66 & 0.10 & 0.23 \\
\hline \multicolumn{6}{|l|}{ Aldehyde } \\
\hline Pentanal & $3.81^{\mathrm{b}}$ & $4.49^{\mathrm{a}}$ & $4.57^{\mathrm{a}}$ & 0.13 & $<0.01$ \\
\hline Hexanal & 4.98 & 5.09 & 5.17 & 0.15 & 0.68 \\
\hline Heptanal & 4.23 & 4.66 & 4.47 & 0.16 & 0.20 \\
\hline Octanal & 3.98 & 4.15 & 4.04 & 0.08 & 0.36 \\
\hline Nonanal & 4.27 & 4.42 & 4.40 & 0.09 & 0.52 \\
\hline 2-Nonenal & 2.63 & 3.49 & 3.86 & 0.53 & 0.28 \\
\hline Benzaldehyde & 4.73 & 4.73 & 4.72 & 0.02 & 0.56 \\
\hline \multicolumn{6}{|l|}{ Alcohol } \\
\hline 1-Pentanol & $4.15^{\mathrm{b}}$ & $4.96^{\mathrm{a}}$ & $4.79^{\mathrm{a}}$ & 0.17 & 0.01 \\
\hline 1-Hexanol & 4.34 & 4.57 & 4.54 & 0.10 & 0.21 \\
\hline 1-Octanol & 4.18 & 4.40 & 4.39 & 0.11 & 0.34 \\
\hline 1-Heptanol & 4.10 & 4.27 & 4.21 & 0.13 & 0.66 \\
\hline 1-Octen-3-ol & 4.40 & 4.52 & 4.44 & 0.11 & 0.73 \\
\hline \multicolumn{6}{|l|}{ Sulfur compound } \\
\hline Dimethyl sulfone & $4.24^{\mathrm{b}}$ & $4.60^{\mathrm{a}}$ & $4.43^{\mathrm{ab}}$ & 0.08 & 0.03 \\
\hline Dimethyl sulfide & 3.43 & 3.66 & 3.48 & 0.11 & 0.34 \\
\hline \multicolumn{6}{|l|}{ Ketone } \\
\hline Acetone & $6.01^{\mathrm{b}}$ & $6.14^{\mathrm{ab}}$ & $6.21^{\mathrm{a}}$ & 0.05 & 0.04 \\
\hline 2-Butanone & $5.26^{\mathrm{b}}$ & $5.41^{\mathrm{ab}}$ & $5.56^{\mathrm{a}}$ & 0.05 & $<0.01$ \\
\hline 2-Pentanone & 4.93 & 4.98 & 5.04 & 0.04 & 0.24 \\
\hline 2-Heptanone & 5.20 & 4.96 & 5.04 & 0.08 & 0.15 \\
\hline 1-Octen-3-one & 3.37 & 3.69 & 4.50 & 0.50 & 0.30 \\
\hline 2-Nonanone & 5.08 & 4.87 & 4.89 & 0.09 & 0.21 \\
\hline 2-Undecanone & 4.79 & 4.71 & 4.69 & 0.04 & 0.32 \\
\hline \multicolumn{6}{|l|}{ Lactone } \\
\hline$\gamma$-Octalactone & 3.83 & 3.78 & 3.72 & 0.05 & 0.26 \\
\hline$\gamma$-Decalactone & $3.95^{\mathrm{a}}$ & $3.77^{\mathrm{ab}}$ & $3.76^{\mathrm{b}}$ & 0.06 & 0.03 \\
\hline$\gamma$-Dodecalactone & $3.91^{\mathrm{a}}$ & $3.54^{\mathrm{b}}$ & $3.43^{\mathrm{b}}$ & 0.09 & $<0.01$ \\
\hline$\gamma$-Dodecaenolactone & $3.77^{\mathrm{a}}$ & $3.44^{\mathrm{ab}}$ & $3.20^{\mathrm{b}}$ & 0.13 & 0.01 \\
\hline D-Hexalactone & 4.38 & 4.19 & 4.28 & 0.09 & 0.21 \\
\hline д-Octalactone & $4.84^{\mathrm{y}}$ & $4.52^{\mathrm{z}}$ & $4.64^{\mathrm{yz}}$ & 0.10 & 0.08 \\
\hline d-Decalactone & 5.50 & 5.38 & 5.30 & 0.08 & 0.14 \\
\hline d-Undecalactone & 3.62 & 3.50 & 3.43 & 0.14 & 0.56 \\
\hline d-Dodecalactone & 5.07 & 4.89 & 4.86 & 0.09 & 0.18 \\
\hline d-Tridecalactone & 4.18 & 4.14 & 4.09 & 0.06 & 0.33 \\
\hline 2-Tetradecalactone & $4.08^{\mathrm{a}}$ & $3.75^{\mathrm{b}}$ & $3.79^{\mathrm{ab}}$ & 0.10 & 0.05 \\
\hline \multicolumn{6}{|l|}{ Terpene } \\
\hline$\alpha$-Pinene & $4.38^{\mathrm{ab}}$ & $4.08^{\mathrm{b}}$ & $4.55^{\mathrm{a}}$ & 0.09 & $<0.01$ \\
\hline D-Limonene & 4.05 & 4.03 & 4.05 & 0.07 & 0.94 \\
\hline \multicolumn{6}{|l|}{ Phenolic compound } \\
\hline Phenol & 4.62 & 4.61 & 4.59 & 0.02 & 0.11 \\
\hline Toluene & $5.36^{\mathrm{b}}$ & $5.89^{\mathrm{a}}$ & $5.25^{\mathrm{b}}$ & 0.04 & $<0.01$ \\
\hline
\end{tabular}

${ }^{\mathrm{a}, \mathrm{b}}$ Within a row, mean values followed by different superscripts are different $(P \leq 0.05)$.

${ }^{\mathrm{y}, \mathrm{z}}$ Within a row, mean values followed by different superscripts are different $(0.05<P<0.10)$.

${ }^{1}$ Levels of milk volatile organic compounds evaluated using a solid-phase microextraction technique and expressed as $\log _{10}$ of the peak area. See Materials and Methods for the description.

${ }^{2}$ Standard error of the mean for 7 measurements. 
ous explanation exists for the higher pentanal detection in milk of cows fed silage, whereas milk fat concentrations of cis-9,cis-12 18:2 were similar for cows fed hay or silage.

According to Moio et al. (1993), primary alcohols are formed by reduction of their respective aldehydes. Consequently, the higher content of 1-pentanol observed in milk of cows fed pasture and silage, compared with hay, is in line with similar differences observed with milk pentanal content (Table 4).

Among the compounds of the ketone family, levels of acetone and 2-butanone were lower for cows fed hay, intermediate for cows fed pasture, and higher for cows fed silage (Table 4). According to Marsili (2003), milk acetone and 2-butanone originate from animal feed. However, very few data are available on the level of ketones in dairy feed ingredients. Morgan and Pereira (1962a,b) reported various concentrations of acetone and 2-butanone in several grass and corn silage samples. This source of ketones in fermented forages may explain the higher values obtained for acetone and 2-butanone in milk of cows fed silage.

Acetone could also be produced endogenously in lactating animals (Marsili, 2003). When cows develop hyperketonemia, adipose tissue mobilization leads to increased serum concentrations of NEFA, which are largely directed to synthesis of ketone bodies in the liver (Drackley et al., 2006). Acetone produced in this way is released in the blood stream and could be excreted in milk. Cows used in the current trial were more than 200 DIM and even if cows on pasture were in moderate negative energy balance and lost weight during the experimental period (Table 2), they showed no signs of ketosis.

The forage types did not affect the detection intensity of $\partial$-lactone in milk, with the exception of greater values for $\partial$-octalactone $(P=0.08)$ and $\partial$-tetradecalactone $(P$ $=0.05)$ in milk of cows fed hay compared with pasture (Table 4). More significant effects were observed on the subfamily of $\gamma$-lactones. Milk contents of $\gamma$-decalactone, $\gamma$-dodecalactone, and $\gamma$-dodecaenolactone were higher in hay-fed cows, lower in silage-fed cows, and intermediate for cows on pasture. Bendall (2001) reported similar nasal detection frequencies for $\gamma$-decalactone, $\gamma$-dodecalactone, and $\gamma$-dodecaenolactone in milk of cows on pasture compared with cows fed TMR. However, a higher nasal detection frequency of $\gamma$-dodecadienolactone was observed with TMR compared with pasture feeding. In the current study, this $\gamma$-lactone was not detected using the SPME technique.

According to Joblin and Hudson (1997), synthesis of $\gamma$-dodecalactone and $\gamma$-dodecaenolactone begins in the rumen and is finalized in animal tissues. In the rumen, C18 unsaturated FA are first transformed by hydra-
Table 5. Results of the triangle test comparing milks from cows fed silage or pasture with milk from cows fed hay

\begin{tabular}{lccc}
\hline Comparison & $\begin{array}{c}\text { Retained } \\
\text { response }\end{array}$ & $\begin{array}{c}\text { Correct } \\
\text { response }\end{array}$ & $\begin{array}{c}\text { Significance } \\
\text { (risk) }\end{array}$ \\
\hline Silage vs. hay & 30 & 12 & 0.28 \\
Pasture vs. hay & 30 & 20 & $<0.01$ \\
\hline
\end{tabular}

tion into hydroxy acid intermediates. After absorption, hydroxy acids are shortened by 3 rounds of $\beta$-oxidation, followed by cyclization to $\gamma$-lactones in animal tissues (Joblin and Hudson, 1997). Dietary cis-9 18:1 and cis-9,cis-12 18:2 are precursors of $\gamma$-dodecalactone and $\gamma$-dodecaenolactone, respectively. However, the reason why the highest levels of $\gamma$-lactones were observed in milk from cows fed hay, which had the lowest forage concentrations of cis-9 18:1 and cis-9,cis-12 18:2 compared with pasture and silage, remains unclear. The concentration of $\gamma$-lactones in milk could be modified by controlling the microbial population responsible for FA hydration in the rumen (Joblin and Hudson, 1997), a phenomenon that was not assessed in the current study.

The content of dimethyl sulfone in milk was greater for cows on pasture, intermediate for cows fed silage, and lower for cows fed hay. Greater concentrations of dimethyl sulfone were reported in milk of cows (Coppa et al., 2011) and ewes (Moio et al., 1996) on pasture compared with those fed hay. In the rumen, dimethyl sulfide is first derived from the catabolism of sulfur amino acids, particularly methionine (Taylor and Kiene, 1989). The metabolic fate of dimethyl sulfide is then oxidation to dimethyl sulfone, which could be transferred to milk. The detection intensity of dimethyl sulfone in milk (Table 4) was well in line with dietary supply of protein, as a source of methionine, which was high in pasture, intermediate in silage, and low in hay (Table 1).

The level of $\alpha$-pinene, as detected by SPME, was lower in milk from cows on pasture, intermediate for cows fed hay, and higher for those fed silage (Table 4). The timothy plot used in this trial was also colonized with white clover (Trifolium repens L.) and fava bean (Vicia faba L.), which both potentially contained a-pinene (Kameoka et al., 1977; Griffiths et al., 1999). It could be hypothesized that cows on pasture were selecting herbage more efficiently while grazing compared with cows fed silage or hay and, therefore, animals on pasture were consuming less of these plants.

Cows on pasture produced milk with a higher level of toluene compared with cows fed hay and silage (Table 4). According to Daun (2005), toluene could be a product of $\beta$-carotene degradation. Forage wilting and sun curing are known to destroy carotenoids when harvest- 
Table 6. Summary of statistics for sensory evaluation of the intensity of total, sweet, and grassy flavors of milk from Holstein cows fed timothy hay, pasture, or silage $(\mathrm{n}=30)$

\begin{tabular}{|c|c|c|c|c|c|}
\hline \multirow[b]{2}{*}{ Timothy forage type } & \multicolumn{3}{|c|}{ Percentage of assessors ranking ${ }^{1}$} & \multicolumn{2}{|c|}{ Statistical summary } \\
\hline & 1 & 2 & 3 & $x^{2}$ & $P$-value \\
\hline \multicolumn{6}{|c|}{ Total flavor (raw milk, fresh milk, farm milk) } \\
\hline Hay & 50.0 & 20.0 & 30.0 & & \\
\hline Pasture & 6.7 & 40.0 & 53.3 & & \\
\hline Silage & 43.3 & 40.0 & 16.7 & & \\
\hline \multicolumn{6}{|c|}{ Sweet flavor (empyreumatic, vanilla, caramel, sugar) } \\
\hline Hay & 13.3 & 40.0 & 46.7 & & \\
\hline Pasture & 53.3 & 23.3 & 23.3 & & \\
\hline Silage & 33.3 & 36.7 & 30.0 & & \\
\hline \multicolumn{6}{|c|}{ Grassy flavor (grass, leafy vegetable, plant) } \\
\hline Hay & 43.3 & 36.7 & 20.0 & & \\
\hline Pasture & 10.0 & 36.7 & 53.3 & & \\
\hline \multirow[t]{2}{*}{ Silage } & 46.7 & 26.7 & 26.7 & & \\
\hline & & & & 8.47 & 0.01 \\
\hline
\end{tabular}

${ }^{1}$ Ranked on a 3 -point scale $(1=$ less intense to $3=$ more intense).

ing forages as silage or hay, and as a consequence, reduce milk concentrations of carotenoids compared with pasture feeding (Nozière et al., 2006). Therefore, cows on pasture possibly consumed more $\beta$-carotene, which could explain the higher levels of toluene in their milk.

Analysis of milk volatile profile allowed the determination of 6 different ester compounds (Table 4). However, none of the identified esters were affected by dietary treatments.

Results from the sensory evaluation using a triangle test are presented in Table 5. Panelists could not detect a difference in flavor between milk from cows fed hay and milk from cows fed silage. However, a significant number of assessors perceived a difference between milk from cows fed hay and milk from cows fed pasture. These results are partially consistent with those of Dubroeucq et al. (2002) who conducted triangle tests to compare milk from cows fed different forage sources. In their series of tests, panelists were able to detect a difference between milk from cows fed hay and milk from cows fed silage or on pasture.

The sensory analysis was completed by a ranking (1 to 3 ) test with a similar panel (Table 6). The percentage of 30 assessors ranking for the total flavor intensity, with sensory descriptors "raw milk," "fresh milk," and "farm milk," was higher for milk from cows on pasture than milks from cows fed hay or silage. Similar treatment differences were observed for the intensity of grassy flavor, with sensory descriptors "grass," "leafy vegetable," and "plant," where the highest value was observed with milk from cows on pasture (Table 6). In a previous study by Croissant et al. (2007), trained panelists also perceived a greater intensity of grassy flavor in milk from cows on pasture than in milk from cows fed indoor TMR. The ranking for the intensity of grassy flavor in the current study is in line with the higher level of pentanal observed in milk from cows on pasture, knowing that a mild increase in milk aldehydes is recognized to produce a "distinct and pleasant herbaceous aroma" (Moio et al., 1993).

Finally, the percentage of assessors ranking for the intensity of sweet flavor, with sensory descriptors "empyreumatic," "vanilla," "caramel," and "sugar," was higher for milk from cows fed hay, compared with milk from cows fed silage or on pasture. The higher ranking for the milk from cows fed hay could be partly explained by its superior levels of $\gamma$-lactones, which are known to provide a sweet and fruity aroma to milk (Bendall, 2001). Moreover, Croissant et al. (2007) reported a lower intensity of sweet flavor in milk of cows on pasture than in milk from cows fed TMR.

\section{CONCLUSIONS}

Organoleptic properties of milk are affected by the type of timothy forage (hay, pasture, or silage) fed to cows. Timothy forages were at a similar stage of development (late heading) when fed as hay, pasture, or silage but they differed in a few nutritive attributes, including CP, fiber, and FA concentrations. Differences in nutrient supplies between forage types partly explained variations in milk volatile compounds and FA profile. Untrained assessors were able to detect specific differences in sensory characteristics between milk from cows fed different forage types. The sensory evaluation was, however, performed once in the current experiment and repeatability of the current observations needs to be assessed. Specific links between the observed variations 
in volatile compounds or FA profile and the sensory attributes of milk remain to be established under various dietary situations. Each volatile organic compound has its own threshold of perception and more research, using different techniques such as GC olfactometry, is needed to evaluate if the magnitude of changes in individual volatile organic compounds observed in the current study has a measurable effect on consumer perception.

\section{ACKNOWLEDGMENTS}

This experiment was funded through the Industrial Research Chair program of the Natural Sciences and Engineering Research Council of Canada (Ottawa, ON, Canada), with industry contributions from the Dairy Farmers of Canada (Ottawa, ON, Canada), Novalait Inc. (Québec, QC, Canada), Valacta (Sainte-Annede-Bellevue, QC, Canada), the Fédération des Producteurs de Lait du Québec (Longueuil, QC, Canada), and the Ministère de l'Agriculture, des Pêcheries et de l'Alimentation du Québec (Québec, QC, Canada). The authors thank administrative and research staff of the Centre de Recherche en Sciences Animales de Deschambault (Deschambault, QC, Canada) for the care provided to cows during the trial. The authors are also grateful to Gabrielle St-Pierre and Micheline Gingras from the Département des Sciences Animales (Université Laval, Québec, QC, Canada) for their assistance in samplings and laboratory analyses.

\section{REFERENCES}

Belitz, H. D., W. Grosch, and P. Schieberle. 2009. Food Chemistry. 4th ed. Springer-Verlag, Berlin and Heidelberg, Germany.

Bendall, J. G. 2001. Aroma compounds of fresh milk from New Zealand cows fed different diets. J. Agric. Food Chem. 49:4825-4832.

Boivin, M., R. Gervais, and P. Y. Chouinard. 2013. Effect of grain and forage fractions of corn silage on milk production and composition in dairy cows. Animal 7:245-254.

Boufaïed, H., P. Y. Chouinard, G. F. Tremblay, H. V. Petit, R. Michaud, and G. Bélanger. 2003. Fatty acids in forages. II. In vitro ruminal biohydrogenation of linolenic and linoleic acids from timothy. Can. J. Anim. Sci. 83:513-522.

Broderick, G. A. 1995. Performance of lactating dairy cows fed either alfalfa silage or alfalfa hay as the sole forage. J. Dairy Sci. 78:320-329.

Canadian Council on Animal Care. 1993. Guide to the Care and Use of Experimental Animals. Vol. 1. E. D. Olfert, B. M. Cross, and A. A. McWilliam, ed. CCAC, Ottawa, ON, Canada.

Chazal, M.-P., Y. Chilliard, and J.-B. Coulon. 1987. Effect of nature of forage on spontaneous lipolysis in milk from cows in late lactation. J. Dairy Res. 54:13-18.

Chilliard, Y. 1982. Variations physiologiques des activités lipasiques et de la lipolyse spontanée dans les laits de vache, de chèvre et de femme: Revue bibliographique. Lait 62:126-154.

Coppa, M., B. Martin, P. Pradel, B. Leotta, A. Priolo, and V. Vasta. 2011. Effect of a hay-based diet or different upland grazing systems on milk volatile compounds. J. Agric. Food Chem. 59:4947-4954.

Couvreur, S., C. Hurtaud, C. Lopez, L. Delaby, and J. L. Peyraud. 2006. The linear relationship between the proportion of fresh grass in the cow diet, milk fatty acid composition, and butter properties. J. Dairy Sci. 89:1956-1969.

Croissant, A. E., S. P. Washburn, L. L. Dean, and M. A. Drake. 2007. Chemical properties and consumer perception of fluid milk from conventional and pasture-based production systems. J. Dairy Sci. 90:4942-4953.

Daun, H. 2005. Produce color and appearance. Pages 191-219 in Produce Degradation: Pathways And Prevention. O. Lamikanra, S. H. Imam, and D. O. Ukuku, ed. CRC Press, Boca Raton, FL.

Demir, R., and Ö. Çakmak. 2007. Investigation on fatty acids in leaves, stems and fruits of some species of Medicago. Int. J. Agric. Biol. 9:934-936.

Dewhurst, R. J., K. J. Shingfield, M. R. F. Lee, and N. D. Scollan. 2006. Increasing the concentrations of beneficial polyunsaturated fatty acids in milk produced by dairy cows in high-forage systems. Anim. Feed Sci. Technol. 131:168-206.

Drackley, J. K., S. S. Donkin, and C. K. Reynolds. 2006. Major advances in fundamental dairy cattle nutrition. J. Dairy Sci. 89:1324-1336.

Dubroeucq, H., B. Martin, A. Ferlay, P. Pradel, I. Verdier-Metz, Y. Chilliard, J. Agabriel, and J. B. Coulon. 2002. Cow's feeding may modify sensory properties of milk. Rencontres Recherches Ruminants 9:351-354.

Griffiths, D. W., G. W. Robertson, T. Shepherd, and G. Ramsay. 1999. Epicuticular waxes and volatiles from faba bean (Vicia faba) flowers. Phytochemistry 52:607-612.

Hurtaud, C., L. Delaby, and J.-L. Peyraud. 2007. The nature of preserved forage changes butter organoleptic properties. Lait $87: 505-519$.

Jenkins, T. C. 2010. Technical note: Common analytical errors yielding inaccurate results during analysis of fatty acids in feed and digesta samples. J. Dairy Sci. 93:1170-1174.

Joblin, K. N., and J. A. Hudson. 1997. Management of milk flavor through the manipulation of rumen microorganisms. Pages 455 463 in Milk Composition, Production and Biotechnology. R. A. S. Welch, D. J. W. Burns, S. R. Davis, A. I. Popay, and C. J. Prosser, ed. CAB International, New York, NY.

Kameoka, H., C.-P. Wang, and K. Tokimitsu. 1977. Terpenoids in the essential oil from the flower of Trifolium repens. Agric. Biol. Chem. 41:1785-1786.

Keady, T. W. J., J. J. Murphy, and D. H. Arrington. 1996. The effects of ensiling on dry-matter intake and milk production by lactating dairy cattle given forage as the sole feed. Grass Forage Sci. 51:131-141.

Macoon, B., L. E. Sollenberger, J. E. Moore, C. R. Staples, J. H. Fike, and K. M. Portier. 2003. Comparison of three techniques for estimating the forage intake of lactating dairy cows on pasture. J. Anim. Sci. 81:2357-2366.

Marsili, R. T. 2003. Flavours and off-flavours in dairy foods. Pages 1069-1081 in Encyclopedia of Dairy Science. H. Roginski, J. W. Fuquay, and P. F. Fox, ed. Academic Press, New York, NY.

Martineau, R., H. Lapierre, D. R. Ouellet, D. Pellerin, and R. Berthiaume. 2007. Effects of the method of conservation of timothy on nitrogen metabolism in lactating dairy cows. J. Dairy Sci. 90:2870-2882.

Meilgaard, M. C., G. V. Civille, and B. T. Carr. 2007. Sensory Evaluation Techniques. 4th ed. CRC Press, Boca Raton, FL.

Mohammed, R., C. S. Stanton, J. J. Kennelly, J. K. G. Kramer, J. F. Mee, D. R. Glimm, M. O'Donovan, and J. J. Murphy. 2009. Grazing cows are more efficient than zero-grazed and grass silage-fed cows in milk rumenic acid production. J. Dairy Sci. 92:3874-3893.

Moio, L., J. Dekimpe, P. Etievant, and F. Addeo. 1993. Neutral volatile compounds in the raw milks from different species. J. Dairy Res. 60:199-213.

Moio, L., L. Rillo, A. Ledda, and F. Addeo. 1996. Odorous constituents of ovine milk in relationship to diet. J. Dairy Sci. 79:1322-1331.

Morgan, M. E., and R. L. Pereira. 1962a. Volatile constituents of grass and corn silage. I. Steam distillates. J. Dairy Sci. 45:457-466.

Morgan, M. E., and R. L. Pereira. 1962b. Volatile constituents of grass and corn silage. II. Gas-entrained aroma. J. Dairy Sci. 45:467471. 
Nozière, P., B. Graulet, A. Lucas, B. Martin, P. Grolier, and M. Doreau. 2006. Carotenoids for ruminants: From forages to dairy products. Anim. Feed Sci. Technol. 131:418-450.

NRC. 2001. Nutrient Requirements of Dairy Cattle. 7th rev. ed. Natl. Acad. Sci., Washington, DC.

Nursten, H. E. 1997. The flavour of milk and dairy products: I. Milk of different kinds, milk powder, butter and cream. Int. J. Dairy Technol. 50:48-56.

O'Brien, R. D. 2008. Fats and Oils: Formulating and Processing for Applications. 3rd ed. CRC Press, Boca Raton, FL.

Palmquist, D. L., A. D. Beaulieu, and D. M. Barbano. 1993. Feed and animal factors influencing milk fat composition. J. Dairy Sci. $76: 1753-1771$

Santos, M. V., Y. Ma, Z. Caplan, and D. M. Barbano. 2003. Sensory threshold of off-flavors caused by proteolysis and lipolysis in milk. J. Dairy Sci. 86:1601-1607.
Shingfield, K. J., P. Salo-Väänänen, E. Pahkala, V. Toivonen, S. Jaakkola, V. Piironen, and P. Huhtanen. 2005. Effect of forage conservation method, concentrate level and propylene glycol on the fatty acid composition and vitamin content of cows' milk. J. Dairy Res. $72: 349-361$

Taylor, B. F., and R. P. Kiene. 1989. Microbial metabolism of dimethyl sulfide. Pages 202-221 in Biogenic Sulfur in the Environment. E. S. Saltzman and W. J. Cooper, ed. Am. Chem. Soc., Washington, DC

Toso, B., G. Procida, and B. Stefanon. 2002. Determination of volatile compounds in cows' milk using headspace GC-MS. J. Dairy Res. 69:569-577.

Urbach, G. 1990. Effect of feed on flavor in dairy foods. J. Dairy Sci. 73:3639-3650 